\title{
ANALISA EFEKTIVITAS PENYALURAN ZAKAT BAZNAS KABUPATEN KUDUS
}

\author{
Muhammad Agus Yusrun Nafi, ${ }^{1}$ \\ ${ }^{1,2}$ Institut Agama Islam Negeri Kudus, Kudus \\ Email. magusyusrunnafi9@gmail.com
}

\begin{abstract}
: The National Zakat Agency (BAZNAS) Kudus Regency is a non-structural government institution that manages zakat in the Kudus Regency area. The problem in this research is how the effectiveness of zakat distribution of BAZNAS in Kudus Regency? The objectives of this study include: to measure the effectiveness of zakat distribution for BAZNAS in Kudus Regency. This research uses qualitative and quantitative methods. The qualitative method uses a descriptive approach. Meanwhile, the quantitative method uses the Zakat Core Principle ratio (ZCP) measurement model. The object used in this study is the BAZNAS financial statements in the first year of 2019. The results of this study indicate that the amount of Zakat collection in 2019 Rp. 2,682,855,379. Meanwhile, the amount of Zakat distribution in 2019 was Rp. 1,856,423,965 Based on the ZCP, the level of effectiveness of distribution in 2019 was operating at $70 \%$ (seventy percent). This shows that the level of effectiveness of BAZNAS zakat distribution in 2019 is in the Effective category where the Allocation to Collection Ratio (ACR) reaches 70 percent - 89 percent.
\end{abstract}

Keywords

: Effectiveness; Distribution; BAZNAS; Zakat Core Principle; Zakat

\section{Latar Belakang}

Seluruh Zakat merupakan salah satu kewajiban bagi orang Islam berupa mendistribusikan harta benda yang dimiliki kepada orang yang berhak sebagaimana telah ditentukan di dalam al-Qur'an dan Hadis sebagai wujud menjaga dan melaksanakan amanat dari Allah SWT (Qardhawi, 2016) Zakat tidak hanya berfungsi hanya sekedar membantu orang lain, namun juga bisa berfungsi lebih, pertama. Sebagai wujud keimanan kepada Allah SWT dengan rasa syukur atas nikmat-Nya mampu menumbuhkan akhlak mulia dengan rasa kemanusiaan yang tinggi, mampu menghilangkan sifat kikir sekaligus mampu membersihkan harta yang dimiliki. Kedua, mampu menolong, membantu, membina para mustahik ke arah kehidupan yang lebih sejahtera. Ketiga, sebagai pilar amal bersama antara orang kaya dengan orang yang seluruh waktunya digunakan untuk

berjihad di jalan Allah. Keempat, sebagai salah satu instrumen pemerataan pendapatan. (Hafidhuddin, 2002a)

Dengan sangat besarnya manfaat zakat kepada masyarakat secara umum, maka pemerintah membentuk BAZNAS (Badan Amil Zakat Nasional) sebagai lembaga yang mengelelo zakat. Menurut Undang-undang RI No. 23 pasal 5 ayat 3 Tahun 2011 tentang Pengelolaan Zakat mengartikan bahwa Badan Amil Zakat Nasional (BAZNAS) merupakan lembaga pemerintah nonstruktural yang bersifat mandiri dan bertanggung jawab dalam pengelolaan zakat kepada Presiden melalui Menteri Agama. Maka dari itu, Baznas 
merupakan salah satu lembaga pemerintah yang bertugas untuk mengelola zakat seutuhnya, yakni dimulai dari pengumpulan, penyaluran, serta pendayagunaan dana zakat kepada masyarakat yang kurang mampu. Guna keefektifan dan keefisienan pengelolaan zakat, maka dalam proses berjalannya, Kementerian Agama membagi Baznas menjadi beberapa wilayah, yakni Baznas Ibu Kota Negara, Baznas Provinsi, dan Baznas Kabupaten/Kota (Husnul Hami Fahrini, 2016). Baznas ini dibentuk untuk mewujudkan fungsi dan perannya sebagai lembaga amil zakat dalam pengelolaan dana zakat untuk 8 golongan penerima zakat, yaitu fakir, miskin, amil, muallaf, riqob (hamba sahaya), gharim, sabilillah, ibnu sabil, sebagaimana yang dijelaskan dalam Surat At-Taubah ayat 60. Akan tetapi di Baznas Kabupaten Kudus masih disalurkan ke fakir miskin, gharim, dan ibnu sabil. Padahal. Menurut pendapat Imam Syafii dalam kitab Wahbah al-Zuhaily, bahwa mazhab Syafii mengatakan zakat wajib dikeluarkan kepada delapan kelompok asnaf.

Sedangkan Baznas Kabupaten Kudus juga memiliki tehnik prosedur tersendiri untuk menyalurkan dana zakat sesuai dengan ketentuan yang berlaku. Prosedurnya dengan kerjasama dengan pemerintah kabupaten, kecamatan, KUA, pemerintah desa dan steakholder untuk diajukan ke BAZNAS yang selanjutnya dari pihak BAZNAS Kabupaten Kudus melakukan survey ke lapangan kaitannya validitas data yang diterima. Dalam usia seumur jagung, BAZNAS Kabupaten Kudus sudah mengadakan penyaluran zakat kepada 19 fakir miskin dengan jenis pemanfaatannya berupa renovasi maupun pembangunan rumah yang tidak layak huni (RTLH), dan masih banyak lagi jenis pemanfaatan yang dilaksanakan oleh BAZNAS Kabupaten Kudus.

Tabel 1.1

\begin{tabular}{|l|l|}
\hline & \multicolumn{1}{|c|}{ TAHUN 2019 } \\
\hline Perhimpunan & 2.682 .855 .379 \\
\hline Penyaluran & 1.856 .423 .965 \\
\hline
\end{tabular}

Sumber: Laporan keuangan internal Baznas Kabupaten Kudus (diolah)

Dari pemaparan pada latar belakang di atas, peneliti tertarik untuk meneliti terhadap penyaluran zakat yang dilakukan oleh BAZNAS Kabupaten Kudus kepada para mustahiq sebagai salah satu wujud melaksanakan amanat Undang-Undang No. 23 tahun 2011 tentang Pengelolaan Zakat yang menjelaskan bahwa tujuan pengeleloan zakat adalah meningkatkan efektivitas dan efisiensi pelayanan dalam pengelolaan zakat dan meningkatkan manfaat zakat untuk mewujudkan kesejahteraan masyarakat dan penanggulangan kemiskinan. Dan melihat data penghimpunan dan penyaluran BAZNAS Kabupaten Kudus tahun 2019 sebagai tahun pertama peneliti tertarik untuk melakukan penelitian mengenai efektivitas penyaluran dana zakat di Baznas Provinsi Jawa Timur yang dihitung melalui rasio ACR (Allocation to Collection Ratio). ACR merupakan rasio perbandingan antara proporsi dana zakat yang dihimpun. Adapun pengkategorian ACR ini dibagi menjadi lima, yakni highly effective (>90\%), effective (70\%-89\%), fairly effective (50\%-69\%), below expectation (20\%-49\%), dan ineffective (<20\%). Pada kategori highly effective memiliki arti bahwa dana zakat yang disalurkan lebih dari $90 \%$ dibandingkan dana zakat diterima. Hal tersebut berarti hak amil yang digunakan kurang dari 10 persen. Keadaan tersebut berarti bahwa semakin besar penggunaan proporsi hak amil, maka semakin rendah kapasitas penyaluran dana zakat pada sebuah lembaga amil zakat, 
sehingga berpengaruh terhadap tingkat efektivitas dalam program penyaluran dana zakat. (Beik, 2016b)

\section{Teori dan Metode}

\subsection{Pengertian Zakat}

Pembicaraan tentang zakat pada hakikat diantara pendapat hampir ada kesamaan semuanya. Zakat ditinjau dai segi bahasa, mempunyai beberapa arti, diantaranya menggunakan arti dari kata al-barakatu artimya keberkahan, al-namaa yang mempunyai arti pertumbuhan dan perkembangan, ath-thahratu yang memiliki arti kesucian dan ashsalahu berarti beresan (Hafidhuddin, 2002). Sedangkan zakat menurut istilah adalah sebuah kewajiban yang diperintahkan kepada umat Islam yang telah memenuhi syarat dengan bentuk memberi sejumlah hartanya kepada orang yang berhak untuk menerimanya sebagaimana kelompok orang yang telah ditentukan oleh syari'at Islam (Sari, 2006). Berangkat dari pemahaman zakat dari segi bahasa maupun istilah, zakat adalah kewajiban yang wajib dilaksanakan oleh umat Islam yang telah memenuhi persyaratan untuk memberikan hartanya kepada orang yang berhak sesuai dengan ketentuan syariat Islam dengan salah satu tujuan agar hartanya berkah, tumbuh, berkembang dan bertambah sebagaimana tertuang dalam surat At-Taubah ayat 103 dan surat Ar-Rum ayat 39.

Lebih lanjut dijelaskan, ada beberapa tujuan diperintahkan zakat sebagai berikut: 1). Mengangkat derajat fakir miskin dan menolongnya untuk keluar dari kesulitan hidup dan penderitaan; 2). Membantu pemecahan permasalahan yang dihadapi oleh gharim, ibnussabil dan mustahiq serta lain-lainnya; 3). Membentangkan dan membina tali persaudaraan sesama umat Islam dan manusia pada umumnya; 4). Menghilangkan sifat kikir dari pemilik harta kekayaan; 5). Membersihkan sifat dengki dan iri pada hati orangorang miskin; 6). Menjembatani pemisah antara yang kaya dengan yang miskin dalam lingkungan masyarakat; 7). Mengembangkan rasa tanggung jawab sosial pada diri seseorang, utamanya pada golongan dengan harta yang melimpah; 8). Mendidik manusia untuk berdisiplin menunaikan kewajiban dan menyerahkan hak orang lain yang menempel pada dirinya; 9). Sebagai saran untuk pemerataan pendapatan guna mencapai keadilan sosial. (Sari, 2006).

Di samping itu, zakatpun memiliki beberapa hikmah dan manfaat sebagai berikut: 1). Sebagai wujud keimanan kepada Allah SWT dengan rasa syukur atas nikmat-Nya, mampu menumbuhkan akhlak mulia dengan rasa kemanusiaan yang tinggi, mampu menghilangkan sifat kikir sekaligus mampu membersihkan harta yang dimiliki; 2). Mampu menolong, membantu, membina para mustahik ke arah kehidupan yang lebih sejahtera. 3). Sebagai pilar amal bersama antara orang kaya dengan orang yang seluruh waktunya digunakan untuk berjihad di jalan Allah; 4). Sebagai salah satu instrumen pemerataan pendapatan (Hafidhuddin, 2002).

Sedangkan zakat dibedakan menjadi dua jenis, yaitu zakat fitrah dan zakat mal. Zakat fitrah merupakan pengeluaran wajib yang dilakukan oleh setiap muslim yang memiliki kelebihan harta dan kebutuhan keluarga sudah tercukup atau dikatakan wajar pada malam hari raya Idul Fitri. Sementara itu, zakat mal merupakan bagian dari harta kekayaan seseorang yang wajib dikeluarkan untuk golongan orang-orang tertentu, dengan ketentuan setelah harta tersebut dipunyai selama jangka waktu tertentu dalam jumlah minimal tertentu6. (Dadang Husen Sobana, Uus Ahmad Husaeni, Irpan Jamil, 2016). 
Adapun zakat dilihat dari aspek jenis zakat dibagi sebagai berikut: 1). Zakat Fitrah, yaitu zakat untuk membersihkn diri yang dibayarkan setiap bulan Ramadhan. Besarnya zakat fitrah yang harus dikeluarkan per individu adalah satu sha' atau setara dengan 2,5 kilogram atau 3,5 liter beras makanan makanan pokok. Zakat ini dibagikan kepada delapan golongan yang berhak menerima zakat, namun untuk fakir dan miskin lebih didahulukan. 2). Zakat Maal, yaitu zakat atas harta kekayaan. Adapun jenis-jenis zakat maal ini diantaranya adalah sebagai berikut: a). Zakat emas dan perak, nishab emas adalah 20 dinar (setara dengan 85 gram emas murni). Sementara itu, nishab perak adalah 200 dirham (setara degan 672 gram perak). Hal ini berarti apabila memiliki emas sebesar 20 dinar selama satu tahun, maka emas tersebut harus dikeluarkan zakatnya sebesar 2,5\%, begitu pula untuk ketentuan perak; b). Zakat harta berharga lainnya, misalnya uang tunai, tabungan saham, obligasi dan lain-lain. Maka besarnya zakat yang harus dikeluarkan dan syarat-syaratnya adalah sama seperti zakat emas dan perak; c). Zakat profesi/penghasilan yaitu zakat yang dikeluarkan dari hasil profesi seseorang sebesar 2,5\%; d). Zakat tabungan, yaitu uang yang telah disimpan selama satu tahun dan mencapai nilai minimum (nisbah) yang setara dengan 85 gram emas, maka zakat yang wajib dikeluarkan adalah sebesar $2,5 \%$; e). Zakat investasi, yaitu zakat yang dikenakan terhadap harta yang diperoleh dari hasil investasi, besarnya adalah 5\% untuk penghasilan kotor dan $10 \%$ untuk penghasilan bersih; f). Zakat perniagaan, yaitu zakat yang dikeluarkan dari hasil perniagaan. Adapun ketentuannya yaitu berjalan 1 tahun nisbah senilai 85 gram emas, besar zakatnya 2,5\% dapat dibayar dengan uang atau barang perdagangan maupun perseroan.7 (Hani, 2015).

Sementara itu, terdapat beberapa jenis harta zakat yang wajib dikeluarkan zakatnya apabila telah memenuhi sifat dan syarat kekayaan, diantaranya adalah sebagai berikut: (Asnaini, 2015) 1). Milik Penuh, hal ini berarti kekayaan yang dikenakan zakat apabila berada di bawah kontrol dan di dalam kekuasaan pemiliknya; 2). Berkembang, hal ini berarti kekayaan yang wajib dikenakan zakat apabila harta dapat berkembang dengan sendirinya atau dikembangkan ; 3). Cukup senisab, yakni semua kekayaan yang wajib dikenakan zakat harus sampai senisab, kecuali tentang hasil pertanian, buah-buahan, dan logam mulia; 4). Lebih dari kebutuhaan biasa, yakni kekayaan yang dimiliki sudah melebihi batas dari kekayaan yang berkembang; 5). Bebas dari hutang, yakni seorang individu yang tidak memiliki hutang wajib mengelurkan zakatnya; 6). Cukup haul, haul berbeda dengan nisab. Jika nisab adalah batas minimum jumlah kekayaan, namun haul adalah batas waktu minimum yakni 1 tahun.

\subsection{Orang-Orang Yang Berhak Menerima Zakat}

Adapun beberapa golongan atau pihak yang berhak menerima zakat berdasarkan ayat Al-Quran Surat At-Taubah ayat 60 diantaranya adalah sebagai berikut:9 (Husnul Hami Fahrini, 2016) 1). Fakir (al-fuqara), yakni orang yang sama sekali tidak mempunyai pekerjaan atau orang yang memiliki pekerjaan tetapi tidak mampu memenuhi kebutuhan pokok yang layak bagi kemanusiaan; 2). Miskin (al-masakin), yakni orang yang memiliki penghasilan untuk memenuhi kebutuhan hidup, akan tetapi tidak memenuhi standar kelayakan hidup yang dibutuhkan.

Adapun beberapa aspek seorang individu dikatakan miskin, diantaranya adalah sebagai berikut: a). tidak memiliki usaha sama sekali; b). memiliki usaha, tetapi hasil usaha tersebut tidak mampu memenuhi kebutuhan dirinya sendiri dan keluarganya; c). sanggup bekerja dan mencari nafkah serta dapat mencukupi dirinya sendiri, akan tetapi mereka 
kekurangan alat ataupun modal; d). tidak mampu mencari nafkah dikarenakan kekurangan non materi, seperti cacat fisik, lumpuh, tuna netra, janda, anak-anak, dan sebagainya.

3). Amil Zakat, yakni pihak yang diangkat oleh pimpinan atau lembaga perkumpulan untuk mengelola zakat. Adapun tugas dari amil diantaranya adalah mengumpulkan zakat dari muzakki, mengatur pembagian zakat dengan adil dan benar, dan menyalurkan zakat kepada pihak yang berhak menerimanya; 4). Muallaf, yaitu orang yang baru masuk islam atau orang yang diharapkan memiliki kecenderungan masuk. Dana zakat ini diberikan kepada muallaf sebagai upaya persuasif yang diberikan agar muallaf tersebut semakin yakin terhadap agama Islam; 5). Hamba Sahaya, yakni dana zakat yang diperuntukkan bagi hamba sahaya untuk memerdekakan dirinya serta menghilangkan segala macam perbudakan; 6). Orang yang berhutang (gharim), yaitu orang yang berhutang bukan untuk keperluan maksiat (perbuatan yang melanggar agama). Gharim merupakan orang yang memiliki kesulitan dalam membayar hutangnya karena tidak memiliki harta yang lebih untuk membayar hutang. Adapun jenis gharim, dibedakan menjadi dua, diantaranya adalah sebagai berikut: a). Berhutang disebabkan oleh kefaqiran serta memiliki kesulitan untuk melunasi hutang dalam jangka waktu yang telah ditentukan; b). Berhutang yang disebabkan oleh kebutuhan yang mendesak, tidak menemukan alternatif selain berhutang dan kemudian mengalami kesulitan saat membayar hutang. 7). Orang yang berjuang di jalan Allah (fisabilillah), yakni seorang individu atau segerombol orang yang berusaha atau mengupayakan untuk kemaslahatan bersama, misalnya adalah mendirikan sekolah gratis, da'i, orang-orang yang sedang menempuh pendidikan, dan lain sebagainya; 8). Orang yang dalam perjalanan (ibnu sabil), yaitu orang yang berhak menerima zakat karena kehabisan bekal dalam perjalanan, dan mereka membutuhkan bekal tersebut untuk memenuhi kebutuhan hidupnya.

\subsection{Penyaluran Dana Zakat}

Penyaluran dana zakat merupakan salah satu unsur atau aspek dari pengelolaan zakat. Undang-Undang Nomor 23 Tahun 2011 tentang Pengelolaan Zakat mendefinisikan bahwa Pengelolaan zakat adalah kegiatan perencanaan, pelaksanaan, dan pengoordinasian dalam pengumpulan, pendistribusian, dan pendayagunaan zakat. Pengelolaan zakat bertujuan: 1). Meningkatkan efektivitas dan efisiensi pelayanan dalam pengelolaan zakat; 2). Meningkatkan manfaat zakat untuk mewujudkan kesejahteraan masyarakat dan penanggulangan kemiskinan. (Undang-Undang Nomor 23 Tahun 2011 Tentang Pengelolaan Zakat, 2011).

Dalam rangka pengumpulan zakat, muzaki melakukan penghitungan sendiri atas kewajiban zakatnya. Dalam hal tidak dapat menghitung sendiri kewajiban zakatnya, muzaki dapat meminta bantuan BAZNAS. Lingkup kewenangan pengumpulan zakat oleh BAZNAS, BAZNAS provinsi, dan BAZNAS kabupaten/kota diatur dalam Peraturan Pemerintah.

Zakat wajib didistribusikan kepada mustahik sesuai dengan syariat Islam. Pendistribusian zakat, sebagaimana dimaksud dalam Pasal 25, dilakukan berdasarkan skala prioritas dengan memperhatikan prinsip pemerataan, keadilan, dan kewilayahan. Zakat dapat didayagunakan untuk usaha produktif dalam rangka penanganan fakir miskin dan peningkatan kualitas umat. Pendayagunaan zakat untuk usaha produktif sebagaimana dimaksud pada ayat (1) dilakukan apabila kebutuhan dasar mustahik telah terpenuhi.

Berdasarkan Peraturan Menteri Agama Republik Indonesia Nomor 52 Tahun 2014 tentang Syarat dan Tata Cara Penghitungan Zakat Mal dan Zakat Fitrah Serta 
Pendayagunaan Zakat Untuk Usaha Produktif, Pendayagunaan zakat untuk usaha produktif dilakukan dengan syarat:11 (Peraturan Menteri Agama Republik Indonesia Nomor 52 Tahun 2014 Tentang Syarat Dan Tata Cara Penghitungan Zakat Mal Dan Zakat Fitrah Serta Pendayagunaan Zakat Untuk Usaha Produktif, 2014); 1). Apabila kebutuhan dasar mustahik telah terpenuhi; 2). memenuhi ketentuan syariah; 3). menghasilkan nilai tambah ekonomi untuk mustahik; dan 4). mustahik berdomisili di wilayah kerja lembaga pengelola zakat.

Pendayagunaan zakat untuk usaha produktif dapat dilakukan paling sedikit memenuhi ketentuan: 1). Penerima manfaat merupakan perorangan atau kelompok yang memenuhi kriteria mustahik; dan 2). Mendapat pendampingan dari amil zakat yang berada di wilayah domisili mustahik.

\subsection{Pendistribusian Zakat}

Pendistribusian adalah penyaluran/ pembagian/ pengiriman barang-barang dan sebagainya kepada orang banyak atau beberapa tempat.12 (Qadratillah, 2011). Jadi pendistribusian zakat adalah penyaluran zakat kepada orang yang berhak menerima (mustahiq zakat) baik secara konsumtif ataupun produktif.

Hal pertama dalam langkah pendistribusian zakat adalah dengan melakukan distribusi lokal atau lebih mengutamakan mustahiq dalam lingkungan terdekat dengan lembaga zakat dibandingkan pendistribusian untuk wilayah lainnya, hal itu dikenal dengan sebutan "centralistic". Kelebihan sistem centralistic dalam pengalokasian zakat adalah memudahkan pendistribusiannya ke setiap provinsi. Hampir di setiap negara Islam memulai pendistribusian zakat dari pusat lalu meluas hingga mencakup banyak daerah. (Qardhawi, 2005) Apabila zakat didistribusikan di luar wilayah zakat itu dikumpulkan sedangan dalam wilayah tersebut masih banyak mustahiq yang membutuhkannya, maka hal itu bertentangan denggan hikmah yang ingin direalisasikan dari adana kewajiban zakat. Dalam kitab Al-Mugni, dijelaskan bahwa maksud dari adanya zakat adalah menutupi kebutuhan fakir miskin. Oleh karena itu, diutamakan pendistribusian zakat kepada fakir miskin di wilayah zakat dikumpulkan.14 (Qardhawi, 2005).

Dari sini, maka disepakati bahwasanya pendistribusian zakat dilakukan dimana zakat tersebut dikumpulkan. Apabila ternyata zakat hanya dipergunakan sebagian saja atau tidak sama sekali karena tidak ada lagi dan tidak ditemukan mustahiq yang berhak menerima di daerah tersebut, maka diperbolehkan zakat didistribusikan ke luar daerah, baik dengan menyerahkan penanganannya kepada pemimpin negara atau kepada lembaga zakat pusat. Allah SWT telah menentukan mustahiq zakat dalam surat at-Taubah ayat 60 . Ayat tersebut menisbatkan bahwa kepemilikan zakat adalah untuk semua kelompok dan semua kelompok memiliki hak yang sama. Atas dasar ini, pengelola zakat tidak diperkenankan mendistribusikan zakat kepada pihak lain di luar mustahiq.

Disini terdapat kaidah umum bahwa pendistribusian yang baik adalah adanya keadilan yang sama di antara semua golongan mustahiq. Maksud adil disini, sebagaimana yang dikatakan Imam Syafi'I adalah dengan menjaga kepentingan masing-masing mustahiq dan juga kemaslahatan umat Islam semampunya. (Qardhawi, 2005). Imam Malik, Abu Hanifah yaitu tidak mewajibkan pembagian zakat pada semua sasaran. Abu Ubaid telah menerima riwayat dari Ibnu Abbas, bahwa ia berkata: "Apabila engkau memberikan zakat pada satu sasaran dari sasaran zakat, maka hal itu cukup bagimu". Imam Sufyan dan ulama Irak (Abu Hanifah dan golongannya) berpendapat, bahwa apabila zakat diberikan kepada salah satu sasaran yang delapan, maka dianggap sah. (Hani, 2015). Tidak ada 
keterangan yang mewajibkan pembagian tiap-tiap zakat itu kepada semua golongan. Begitu juga tidak dapat di ambil sebagai alasan hadist Nabi SAW. Yang menyuruh Mu'adz agar mengambil zakat dari orang kaya di antara penduduk Yaman dan menyerahkanya kepada orang-orang miskin. Di antara mereka karena itu merupakan zakat dari jamaah atau kelompok muslimin dan ternyata diberikan hanyalah pada salah satu jenis dari golongan yang delapan. (Sabiq, 2006). Hal tersebut terdapat perbedaan pendapat menurut Imam Syafi'i yaitu dalam kitabnya Al-Umm tidak mengatakan secara langsung mengenai penyamarataan pembagian zakat kepada asnaf zakat, tetapi mengenai pendapat Imam Syafie $i$ tersebut penulis temukan dalam kitabnya Wahbah Al-Zuhaily bahwa mazhab Syafie' i mengatakan, zakat wajib dikeluarkan kepada delapan kelompok manusia, baik itu zakat fitrah maupun zakat mal, berdasarkan QS At-Taubah Ayat: 60.18 (Al-Zuhaily, 1995). maksudnya adalah zakat wajib diberikan kepada delapan kelompok jika semua kelompok itu ada. Jika tidak, zakat itu hanya diberikan kepada kelompok yang ada saja. Sebagaimana ia memberikan contoh dalam kitab Al-Umm.

Dalam hal ini, terdapat kaidah pendistribusian zakat dari beberapa pendapat, penegasan dan pentarjihan dari para ulama fiqih : a). Zakat sebaiknya dibagikan kepada semua mustahiq apabila harta zakat itu banyak dan semua golongan mustahiq ada. Tidak boleh menghalang-halangi satu golongan pun untuk mendapatkan zakat,apabila itu merupakan haknya serta benar-benar dibutuhkan. Hal ini hanya berlaku bagi imam yang mengumpulkan zakat dan membagikannya pada mustahiq. b). Tidak diwajibkan mempersamakan pemberian bagian zakat kepada semua golongan mustahiq, semua tergantung pada jumlah dan kebutuhannya. Karena terkadang pada suatu daerah terdapat seribu orang fakir, sementara jumlah orang yang mempunyai hutang (garim) atau ibnu sabil hanya sepuluh orang. Jadi lebih baik mendahulukan sasaran yang paling banyak jumlah dan kebutuhannya dengan bagian yang besar. c). Diperbolehkan memberikan semua zakat pada sebagian golongan tertentu, demi mewujudkan kemaslahatan yang sesuai dengan syari'ah. Begitu juga ketika memberikan zakat pada salah satu golongan saja, diperbolehkan melebihkan bagian zakat antara satu individu dengan lainnya sesuai dengan kebutuhan karena sesungguhnya kebutuhan itu berbeda antara satu dengan yang lain. Hal yang paling penting adalah jika terdapat kelebihan dana zakat, maka harus berdasarkan sebab yang benar dan demi kemaslahatan bukan disebabkan hawa nafsu atau keinginan tertentu dan tidak boleh merugikan golongan mustahiq atau pribadi lain. d). Hendaknya golongan fakir dan miskin adalah sasaran pertama dalam mendistribusikan zakat, karena memberi kecukupan kepada mereka merupakan tujuan utama dari zakat. e). Apabila dana zakat itu sedikit seperti harta perorangan yang tidak begitu besar, maka boleh diberikkan pada satu golongan mustahiq bahkan satu orang saja. Karena membagikan dana zakat yang sedikit untuk golongan yang banyak atau orang banyak dari satu golongan mustahiq, sama dengan menghilangkan kegunaan yang diharapkan dari zakat itu sendiri. f). Hendaknya mengambil pendapat mazhab Syafi'I dalam menentukan batas yang paling tinggi dalam memberikan zakat kepada petugas yang mengumpulkan dan mendistribusikan zakat (amil), yaitu 1/8 dari dana zakat yang terkumpul dan tidak boleh lebih dari itu. (Qardawi, 1991).

\subsection{Efektivitas}

Berdasarkan kamus Besar Bahasa Indonesia, efektif berarti suatu pencapaian tujuan secara tepat atau memilih tujuan-tujuan yang tepat dari serangkaian alternatif atau pilihan cara dan menentukan pilihan dari berbagai pilihan lainnya. Sementara itu, Hidayat 
mendefinisikan efektivitas sebagai suatu ukuran yang menyatakan seberapa jauh target telah tercapai, yang mana semakin besar presentase target yang dicapai, maka semakin tinggi tingkat efektifitasnya. (Sucahyowati, 2010). Definisi lain dari efektivitas yaitu tolok ukur yang memberikan gambaran terkait seberapa jauh target dapat dicapai. (Umar, 2008).

Efektivitas juga dapat diartikan sebagai suatu ketercapaian atau keberhasilan suatu tujuan yang sesuai dengan rencana dan kebutuhan yang diperlukan, baik dalam penggunaan data, sarana maupun waktunya. (Umar, 2008) Berdasarkan beberapa definisi di atas, dapat disimpulkan bahwa efektivitas merupakan bentuk keberhasilan dari suatu kegiatan yang disesuaikan dengan target atau tujuan. Dengan kata lain, suatu kegiatan dapat dikatakan efektif apabila kegiatan tersebut dapat diselesaikan pada waktu yang tepat dan mencapai tujuan sebagaimana yang diharapkan. Sementara itu, Gibson mengungkapkan bahwa efektivitas dapat diukur dari beberapa kriteria sebagai berikut: (S, 2005) 1). Kejelasan tujuan yang hendak dicapai; 2). Kejelasan strategi pencapaian tujuan; 3). Proses analisis dan perumusan kebijaksanaan yang mantap; 4). Perencanaan yang matang; 5). Penyusunan program yang tepat; 6). Tersedianya sarana dan prasarana; 7). Sitem pengawasan dan pengendalian yang bersifat mendidik.

\subsection{ACR (Allocation to Collection Ratio)}

Efektifitas yang digunakan dalam penelitian ini adalah melalui rasio ACR (Allocation to Collection Ratio), yakni merupakan perbandingan antara jumlah zakat yang disalurkan dengan jumlah zakat yang dihimpun. Perhitungan ini sangat penting digunakan sebagai indikator kinerja penyaluran zakat lembaga yang ada. Apabila suatu lembaga memiliki nilai ACR 90 persen, maka berarti bahwa 90 persen zakat yang dihimpun telah disalurkan. Amil menggunakan dana sebanyak 10 persen untuk memenuhi seluruh kegiatan operasionalnya. Hal tersebut memberikan makna bahwa semakin rendah prosentase nilai ACR menunjukkan semakin lemahnya kemampuan manajemen penyaluran lembaga zakat. Adanya keadaan tersebut, sehingga diperlukan langkah untuk memperbaikinya.

Senada dengan pernyataan tersebut, Beik juga mengungkapkan bahwa ACR merupakan rasio perbandingan antara proporsi dana zakat yang disalurkan dengan dana zakat yang dihimpun. Adapun lima kategori nilai ACR ini, yaitu kategori highly effective (>90 persen), effective (70 persen - 89 persen), fairly effective (50 persen - 69 persen), below expectation (20 persen - 49 persen), dan ineffective. Pada kategori pertama memberikan arti bahwa proporsi dana zakat yang disalurkan lebih dari 90 persen dibandingkan dengan dana zakat yang diterima. Hak amil yang digunakan kurang dari 10 persen. Ini menunjukkan bahwa lembaga zakat memiliki kapasitas penghimpunan dan penyaluran yang sangat besar.

Adapun pada kategori kedua, proporsi penyaluran zakat dibandingkan dengan penghimpunannya berkisar diantara 70 persen hingga 89 persen. Ini berarti hak amil yang digunakan mencapai angka 11 persen hingga 30 persen. Semakin besar penggunaan proporsi hak amil, maka semakin rendah kapasitas penghimpunan dan penyaluran suatu lembaga zakat, sehingga tingkat efektivitas program penyaluran zakat menjadi semakin rendah. (Beik, 2016) 
Indikator kinerja untuk lembaga zakat diwajibkan untuk memastikan bahwa institusi tersebut berfungsi dengan baik sebagaimana mestinya. Indikator tersebut harus mencakup beberapa bidang utama seperti: periode pendistribusian, keefektifan alokasi dana, rasio biaya operasional untuk mengumpulkan dana, kualitas tata pemerintahan, kualitas program pendistribusian, dana maksimum yang dapat dipertahankan atau diangkut dll. Salah satu indikator yang digunakan yaitu dengan melihat ke efektifan pendistribusian dana zakat, dengan indikator tersebut pengawas zakat dapat mengetahui bahwa dana zakat yang didistribusikan sudah maksimal atau belum.

Pengawas Manajemen Pendistribusian zakat dapat menentukan bahwa lembaga zakat memiliki kebijakan dan proses yang memadai untuk mengelola dana zakat dan sistem distribusi. (Beik, 2016). Pengawas zakat dapat menilai tingkat pengelolaan pendistribusian dengan menggunakan rasio allocation-to-collection ratio (ACR). Rasio ini mengkuantifikasi kemampuan lembaga zakat untuk mendistribusikan dana zakat dengan membagi total penyaluran dana zakat dengan total penghimpunan dana zakat.

\subsection{Metode penelitian}

Penelitian ini menggunakan metode penggabungan antara metode kualitatif dan kuantitaif. Penelitian kualitatif adalah penelitian yang bermaksud untuk memahami fenomena tentang apa yang dialami oleh subjek penelitian misalnya perilaku, persepsi, motivasi, tindakan, dan lain-lain secara holistik. Pendekatan yang dilakukan adalah dengan cara deskripsi dalam bentuk kata-kata dan bahasa, pada suatu konteks khusus yang alamiah dan dengan memanfaatkan berbagai metode alamiah (Kuntjojo, 2009, hal. 14-15).

Sedangkan penelitian kuantitatif adalah suatu proses menemukan pengetahuan yang menggunakan data berupa angka sebagai alat menganalisis keterangan mengenai apa yang ingin diketahui. Metode kualitatif pada penelitian ini menggunakan pendekatan deskriptif dan studi literatur. Sedangkan metode kuantitatif dengan menggunakan rasio pengukuran Zakat Core Principle. Objek yang digunakan dalam penelitian ini adalah laporan penyaluran BAZNAS selama rentang periode 2019 sampai dengan 2020. Penelitian ini dibatasi di Badan Amil Zakat Nasional untuk periode pelaporan penyaluran tahun 2019.

\section{Hasil dan Pembahasan}

\subsection{Mengenal Badan Amil Zakat Nasional (BAZNAS) Kabupaten Kudus}

Badan Amil Zakat Nasional (BAZNAS) Kabupaten Kudus merupakan salah satu BAZNAS tingkat kabupaten yang merupkan badan resmi dan dibentuk oleh Bupati Kudus berdasarkan Surat Keputusan Bupati Nomor 451.1.2/058/2018 dengan tertanggal 24 April 2018 dengan dua pimpinan (Drs. H. Aris Samsul Ma'arif selaku ketua dan KH Makruf Sidiq, Lc selaku Wakil Ketua), yang sebelumnya diadakan pemilihan calon pimpinan Badan Amil Zakat Nasional ( BAZNAS ) Kabupaten Kudus oleh tim seleksi yang dibentuk berdasar Keputusan Bupati Kudus Nomor 451/229/2017 tentang Pembentukan Tim Seleksi Pemilihan BAZNAS Kabupaten Kudus 2017 - 2022 sebagaimana tertuang dalam Berita Acara Rapat Koordinasi Penetapan Calon Pimpinan BAZNAS Kabupaten Kudus 2017 - 2022 Nomor 06/Timsel-Panbaz/kds/2018 tanggal 30 Januari 2018, serta pertimbangan Badan Amil Zakat Nasional (BAZNAS) tanggal 10 Rajab 1439 H/28 Maret 
2018 M dengan Nomor 275/ANG/BAznas/III/2018 perihal jawaban permohonan pertimbangan pimpinan BAZNAS Kabupaten Kudus. Lembaga ini mempunyai tugas dan fungsi menghimpun dan menyalurkan zakat, infaq dan sedekah (ZIS) pada tingkat kabupaten, khususnya kabupaten Kudus, dengan dikuatkan oleh Undang-Undang Nomor 23 tahun 2011 tentang Pengelolaan Zakat untuk mengukukuhkan peran BAZNAS Kudus sebagai lembaga yang berwenang melakukan pengelolaan zakat tingkat kabupaten Kudus.

BAZNAS kabupaten Kudus berkedudukan di kabupaten Kudus merupakan lembaga pemerintah non structural yang bersifat mandiri dan bertanggungjawab kepada Bupati, yang mempunyai 4 fungsi penyelenggaraan: Pertama. Perencanaan pengumpulan, pendidtribusian, dan pendayagunaan zakat. Kedua, pelaksanaan pengumpulan, pendistribusian dan pendayagunaan zakat. Ketiga, pengendalian pengumpulan, pendistribusian dan pendayagunaan zakat. Keempat, pelaporan dan pertanggungjawaban pelaksanaan pengelolaan zakat.

Mulai tahun 2019 sampai dengan bulan Agustus 2020 , BAZNAS Kabupaten Kudus masih dipimpin oleh dua orang pimpinan sehingga memaksimalkan kinerja keseketariatan untuk melaksanakan program didampingi dengan pengurus pelaksana lainnya. Namun dalam waktu dekat, akan ada pemilihan pimpinan BAZNAS yang masih kosong tersebut.

\subsection{Pegumpulan dan Penyaluran BAZNAS Kabupaten Kudus}

Mulai 2019 sampai dengan bulan Agustus 2020 Badan Amil Zakat Nasional (BAZNAS) kabupaten Kudus melaksanakan amanah sebagai perpanjangan BAZNAS untuk mengumpulkan zakat, infaq dari pegawai negeri atau ASN di daerah kabupaten Kudus yang bermula tidak atau sedikit terkumpul di organisasi pengumpul zakat yang semacam BAZNAS ini. Di tahun pertama, tahun 2019 sampai dengan bulan Desember 2019, BAZNAS kabupaten Kudus dapat mengumpulkan zakat profesi dari ASN di daerah kabupaten Kudus sekitar Rp 2.682.855.379. Dan di tahun kedua, tahun 2020 sampai bulan agustus 2020 telah terkumpul dari zakat profesi ASN di daerah kabupaten Kudus sekitar Rp 1.639.656.315.

Sedangkan BAZNAS Kabupaten Kudus dalam penyaluran pada tahun 2019, yang pertama adalah penyaluran berupa santunan terhadap fakir miskin sebanyak 3351 orang dengan rincian perorangannya mendapatkan bantuan Rp 100.000,-.Penyaluran kedua, adalah penyaluran terhadap fakir miskin sebanyak 270 orang berupa modal dengan rincian untuk setiap fakir miskin tersebut mendapatkan bantuan Rp 2.000.000,-. Penyaluran ketiga adalah penyaluran terhadap fakir miskin yang termasuk orang yang mempunyai rumah tidak layak huni (RTLH) berupa renovasi maupun pembangunan rumah sebanyak 19 dengan rincian persatunya mendapatkan bantuan berkisar 15 - 35 juta dengan mempertimbangkan kebutuhan rumah tersebut. Penyaluran keempat adalah penyaluran terhadap fakir miskin sebanyak 75 berupa pengobatan yang dibutuhkan mereka dengan rincian perorangnya mendapatkan berkisar Rp. 200.00,- sampai dengan Rp 1.200.000,Penyaluran kelima adalah penyaluran tehadap gharim (orang yang mempunyai hutang) sebanyak 83 orang berupa bantuan pembayaran biaya pendidikan yang belum bisa melunasinya, dengan rincian persatunya mendapatkan bantuan 2 juta. Penyaluran keenam, adalah penyaluran santunan terhadap mustahik yang termasuk fi sabillah (berjuang di jalan 
Allah) sebanyak 703 orang sebagai merbot masjid dengan rincian perorangnya Rp 300.000,-

Pada tahun 2020, mulai januari sampai dengan agustus 2020, yang pertama adalah penyaluran berupa santunan terhadap fakir miskin sebanyak 2116 orang dengan rincian perorangannya mendapatkan bantuan Rp 100.000,-.Penyaluran kedua, adalah penyaluran terhadap fakir miskin sebanyak 26 orang berupa modal usaha dengan rincian untuk setiap fakir miskin tersebut mendapatkan bantuan Rp 2.000.000,-.Penyaluran ketiga adalah penyaluran terhadap fakir miskin yang termasuk orang yang mempunyai rumah tidak layak huni (RTLH) berupa renovasi maupun pembangunan rumah sebanyak 8 dengan rincian persatunya mendapatkan bantuan berkisar 15 - 35 juta dengan mempertimbangkan kebutuhan rumah tersebut. Penyaluran keempat adalah penyaluran terhadap fakir miskin sebanyak 1 berupa pengobatan yang dibutuhkan mereka dengan rincian perorangnya mendapatkan berkisar Rp. 200.00,- sampai dengan Rp 1.200.000,-Penyaluran kelima adalah penyaluran tehadap gharim (orang yang mempunyai hutang) sebanyak 102 orang berupa bantuan pembayaran biaya pendidikan yang belum bisa melunasinya, dengan rincian persatunya mendapatkan bantuan 2 juta. Penyaluran keenam, adalah penyaluran santunan terhadap mustahik yang termasuk fi sabillah (berjuang di jalan Allah) sebanyak 703 orang sebagai merbot masjid dengan rincian perorangnya Rp 300.000,-. Untuk tahun 2020 ini, ada penambahan jenis pemanfaat, yakni penstasyarufan 15.500 orang dikarenakan menyikapi masa pandemi covid19, bantuan kaki palsu terhadap 5 orang dan berupa bantuan kursi roda terhadap satu orang.

Dalam proses penyaluran zakat, BAZNAS kabupaten Kudus mengedepankan kepada pihak yang berhak dan lebih membutuhnya sehingga penyaluran zakat antara tahun 2019 dengan tahun 2020 ada yang berbeda dan juga ada yang tetap sama jenis pemanfaatnya dikarenakan masih dibutuhkannya.

\subsection{Analisa Efektivitas Penyaluran zakat oleh BAZNAS Kabupaten Kudus}

Melihat proses pengumpulan zakat yang dilakukan oleh BAZNAS kabupaten Kudus, terbilang kurang tersistematis dikarenakan pimpinan BAZNAS Kudus masih terbatas dua orang pimpinan sehingga gerak dalam pelaksanaan amanat BAZNAS Kudus belum maksimal karena terkendala dengan pimpinan yang belum menyampaikan 5 orang pimpinan karena sebagai organisasi mestinya jumlah pimpinan sesuai dengan standart opersional yang berlaku, sehinggal secara manajerial bisa mendapatkan hasil yang memuaskan. Karena dalam melaksanakan pengumpulan zakat pertama (tahun 2019) dengan adanya pendekatan kepada pimpinan daerah, bupati misalkan, untuk menginstruksikan kepada ASN bawahannya untuk pelaksanaan pengumpulan zakat ke BAZNAS Kudus sehingga ketika pemangku kebijakan tersebut sudah purna secara langsung atau tidak langsung, dan aturan serta manejemennya tidak optmal, maka niscaya tidak abadi, minimal adanya pengurangan.

Oleh karena, sebagai organisasi mestinya harus mempunyai visi, misi dan tujuan, walaupun hanya perpanjangan dari BAZNAS pusat agar bisa digunakan sebagai acuan pembuatan program maupun pelaksanaan program tersebut, dan sekaligus sebagai acuan untuk evaluasi untuk perkembangan BAZNAS berikutnya.

Penyaluran yang dilaksanakan oleh BAZNAS kabupaten Kudus secara sudah terbilang bagus karena selaku organisasi yang masih berumur jagung, sudah banyak 
menstasarufkan zakat ke beberapa jenis pemanfaatannya. Walaupun demikian, tetap perlu ada upaya peningkatan dalam system dan managemen serta kualitas dan kuantitas nilai zakat yang disalurkan karena melihat perkembangan dari tahun 2019 sampai tahun 2020 (tahunnya belum selesai) di salah satu bidang, ada sedikit kemunduran, walaupun di sesuaikan dengan kebutuhan seperti saat ini dalam musim pandemi covid 19.

Melihat data penghimpunan dan penyaluran dana Zakat di Baznas Kabupaten Kudus pada tahun 2019 pada tabel di bawah ini :

Tabel 1.1

\begin{tabular}{|l|c|}
\hline & TAHUN 2019 \\
\hline Perhimpunan & 2.682 .855 .379 \\
\hline Penyaluran & 1.856 .423 .965 \\
\hline Saldo & 826.431 .414 \\
\hline & $70 \%$ \\
\hline
\end{tabular}

Sumber: Laporan keuangan internal Baznas Kabupaten Kudus (diolah)

Berdasarkan tabel di atas, maka kategori ACR pada tahun 2019 adalah effective. Hal ini sebagaimana yang diungkapkan oleh Beik bahwa terdapat lima kategori nilai ACR, yaitu kategori highly effective (>90 persen), effective (70 persen - 89 persen), fairly effective (50 persen - 69 persen), below expectation (20 persen - 49 persen), dan ineffective. (Beik, 2016) Pada kategori tahun 2019 memberikan arti bahwa proporsi dana zakat yang disalurkan sebesar $70 \%$ dibandingkan dengan dana zakat yang diterima. Ini menunjukkan bahwa lembaga zakat memiliki kapasitas penghimpunan dan penyaluran yang efektif (effective) karena penyaluran dana 70 persen - 89 persen dan sisanya $30 \%$ masuk pada saldo.

\section{Simpulan}

Hasil Berdasarkan kondisi di atas, maka secara garis besar dapat disimpulkan bahwa penyaluran dana zakat di BAZNAS Kabupaten Kudus efektif (effective), sebab dilihat dari penyaluran dana tahun 2019 sebagai pertama. Hal tersebut memberikan arti bahwa BAZNAS Kabupaten Kudus berusaha meningkatkan dana penghimpunannya dan efektif disalurkan sampai mencapai $>90 \%$ (highly effective).

Harapan peneliti supaya BAZNAS Kabupaten Kudus sebaiknya lebih ditingkatkan terus target penghimpunan dananya agar penyaluran dana zakat lebih besar. Selain itu, juga agar tidak menggunakan dana infaq dan shodaqoh untuk menutupi kekurangan dana pada penyaluran zakat. Untuk peneliti selanjutnya, hendaknya lebih mengembangkan dengan metode lainnya, misalnya dengan angket atau kuesioner yang disebarkan melalui web dan ditujukan kepada seluruh UPZ, LAZ. Sehingga dapat diketahui UPZ, LAZ mana sajakah yang sudah efektif dan belum. 


\section{DAFTAR PUSTAKA}

Al-Zuhaily, W. (1995). Zakat Kajian Berbagai Madzhab. Remaja Rosdakarya.

Asnaini. (2015). Optimalisasi Zakat Dalam Ekonomi Islam (Studi Terhadap Sumber Zakat Dan Pengembangannya Di Indonesia). Jurnal Al-'Adl, Vol. $8 \mathrm{No}$.

Beik, I. S. (2016a). Baznas dan Penguatan Zakat di 2016. In Pusat Baznas. http://pusat.baznas.go.id/posko-aceh/baznas-dan-penguatan-zakat-di-2016/

Beik, I. S. (2016b). Meningkatkan Efektivitas Penyaluran Zakat. Jurnal Ekonomi Islam Republika.

Dadang Husen Sobana, Uus Ahmad Husaeni, Irpan Jamil, dan D. S. (2016). The Variables that Affect Compliance of Muslim Merchants for Zakat Maal in the District of Cianjur. International Journal of Zakat 1.

Hafidhuddin, D. (2002b). Zakat Dalam Perekonomian Modern. Gema Insani.

Hani, U. (2015). Analisis Tentang Penyamarataan Pembagian Zakat Kepada Asnaf Zakat Menurut Pendapat Imam Syafi'I. Jurnal Ekonomi Syariahdan Hukum Ekonomi Syariah Al-Iqtishadiyah, Volume: II.

Husnul Hami Fahrini. (2016). Efektivitas Program Penyaluran Dana Zakat Profesi Dalam Bentuk Pemberian Beasiswa Bagi Siswa Muslim Kurang Mampu oleh Badan Amil Zakat Nasional (BAZNAS) di Kabupaten Tabanan Tahun 2015. ). Jurnal Program Studi Pendidikan Ekonomi (JPPE), Volume: 7.

Peraturan Menteri Agama Republik Indonesia Nomor 52 Tahun 2014 tentang Syarat dan Tata Cara Penghitungan Zakat Mal dan Zakat Fitrah Serta Pendayagunaan Zakat Untuk Usaha Produktif. (2014).

Qadratillah, M. T. (2011). Kamus Bahasa Indonesia untuk Pelajar. Badan Pengembangan dan Pembinaan Bahasa, Kementrian Pendidikan dan Kebudayaan.

Qardawi, Y. (1991). Hukum Zakat: Studi Komparatif Mengenai Status dan Filsafat Zakat Berdasarkan Qur'an dan Hadis, (Terj. Salman Harun, et al, Fiqhuz Zakat). PT Pustaka Litera Antar Nusa.

Qardhawi. (2016). Hukum Zakat. Lentera Nusa.

Qardhawi, Y. (2005). Spektrum Zakat dalam Membangun Ekonomi Kerakyatan (Terj. Sari Narulita, Dauru az-Zakah Fi ilaj al-Musykilat al-Iqtisadiyah). Zikrul Media Intelektual.

S, H. N. (2005). Manajemen Publik. Gratiskan. 
Sabiq, S. (2006). Fiqh Sunnah. Pena Pundi Aksara.

Sari, E. K. (2006). Pengantar Hukum Zakat dan Wakaf. Grasindo.

Sucahyowati, H. (2010). Manajemen Sebuah Pengantar. Grafindo.

Umar, H. (2008). Strategic Management in Action. Kanisius.

Undang-Undang Nomor 23 Tahun 2011 tentang Pengelolaan Zakat. (2011).

Al-Zuhaily, W. (1995). Zakat Kajian Berbagai Madzhab. Remaja Rosdakarya.

Asnaini. (2015). Optimalisasi Zakat Dalam Ekonomi Islam (Studi Terhadap Sumber Zakat Dan Pengembangannya Di Indonesia). Jurnal Al-'Adl, Vol. 8 No.

Beik, I. S. (2016a). Baznas dan Penguatan Zakat di 2016. In Pusat Baznas. http://pusat.baznas.go.id/posko-aceh/baznas-dan-penguatan-zakat-di-2016/

Beik, I. S. (2016b). Meningkatkan Efektivitas Penyaluran Zakat. Jurnal Ekonomi Islam Republika.

Dadang Husen Sobana, Uus Ahmad Husaeni, Irpan Jamil, dan D. S. (2016). The Variables that Affect Compliance of Muslim Merchants for Zakat Maal in the District of Cianjur. International Journal of Zakat 1.

Hafidhuddin. (2002a). Zakat Dalam Perekonomian Modern. Gema Insani.

Hafidhuddin, D. (2002b). Zakat Dalam Perekonomian Modern. Gema Insani.

Hani, U. (2015). Analisis Tentang Penyamarataan Pembagian Zakat Kepada Asnaf Zakat Menurut Pendapat Imam Syafi'I. Jurnal Ekonomi Syariahdan Hukum Ekonomi Syariah Al- Iqtishadiyah, Volume: II.

Husnul Hami Fahrini. (2016). Efektivitas Program Penyaluran Dana Zakat Profesi Dalam Bentuk Pemberian Beasiswa Bagi Siswa Muslim Kurang Mampu oleh Badan Amil Zakat Nasional (BAZNAS) di Kabupaten Tabanan Tahun 2015. ). Jurnal Program Studi Pendidikan Ekonomi (JPPE), Volume: 7.

Peraturan Menteri Agama Republik Indonesia Nomor 52 Tahun 2014 tentang Syarat dan Tata Cara Penghitungan Zakat Mal dan Zakat Fitrah Serta Pendayagunaan Zakat Untuk Usaha Produktif. (2014).

Qadratillah, M. T. (2011). Kamus Bahasa Indonesia untuk Pelajar. Badan Pengembangan dan Pembinaan Bahasa, Kementrian Pendidikan dan Kebudayaan.

Qardawi, Y. (1991). Hukum Zakat: Studi Komparatif Mengenai Status dan Filsafat Zakat Berdasarkan Qur'an dan Hadis, (Terj. Salman Harun, et al, Fiqhuz Zakat). PT Pustaka Litera Antar Nusa.

Qardhawi. (2016). Hukum Zakat. Lentera Nusa. 
Qardhawi, Y. (2005). Spektrum Zakat dalam Membangun Ekonomi Kerakyatan (Terj. Sari Narulita, Dauru az-Zakah Fi ilaj al-Musykilat al-Iqtisadiyah). Zikrul Media Intelektual.

S, H. N. (2005). Manajemen Publik. Gratiskan.

Sabiq, S. (2006). Fiqh Sunnah. Pena Pundi Aksara.

Sari, E. K. (2006). Pengantar Hukum Zakat dan Wakaf. Grasindo.

Sucahyowati, H. (2010). Manajemen Sebuah Pengantar. Grafindo.

Umar, H. (2008). Strategic Management in Action. Kanisius. 